\title{
High dissolved extracellular enzymatic activity in the deep central Atlantic Ocean
}

\author{
Federico Baltar ${ }^{1, *}$, Javier Arístegui ${ }^{1}$, Josep M. Gasol ${ }^{2}$, Eva Sintes ${ }^{3}$, \\ Hendrik M. van Aken ${ }^{3}$, Gerhard J. Herndl ${ }^{3,4}$ \\ ${ }^{1}$ Facultad de Ciencias del Mar, Universidad de Las Palmas de Gran Canaria, Campus Universitario de Tafira, \\ 35017 Las Palmas de Gran Canaria, Spain \\ ${ }^{2}$ Departament de Biologia Marina i Oceanografia, Institut de Ciències del Mar - CSIC, Pg. Marítim de la Barceloneta 37-49, \\ 08003 Barcelona, Spain \\ ${ }^{3}$ Department of Biological Oceanography, Royal Netherlands Institute for Sea Research (NIOZ), PO Box 59, \\ 1790 AB Den Burg, The Netherlands \\ ${ }^{4}$ University of Vienna, Ecology Center, Department of Marine Biology, Althanstr. 14, 1090 Vienna, Austria
}

\begin{abstract}
The distribution of prokaryotic abundance (PA), prokaryotic heterotrophic production (PHP), and suspended particulate organic material (POM), as well as total and dissolved (operationally defined as passing through $0.2 \mu \mathrm{m}$ pore size filters) potential extracellular enzymatic activities (EEA; $\alpha$ - and $\beta$-glucosidase [AGase and BGase], leucine aminopeptidase [LAPase], and alkaline phosphatase [APase]) were determined in the meso- and bathypelagic waters of the (sub)tropical Atlantic along an eastern zonal transatlantic transect and a western N-S transect. Significant differences between both transects were found for POM concentration but not for PA, PHP (except in the subsurface and oxygen minimum layer), and dissolved and total EEA. PHP decreased by 3 orders of magnitude from the lower euphotic zone to bathypelagic waters, while PA and cell-specific PHP decreased only by 1 and 2 orders of magnitude, respectively. The proportion of the dissolved to the total EEA was high in the dark ocean for all the enzymes, ranging from 54 to 100 , 56 to 100, 65 to 100 and 57 to $97 \%$ for AGase, BGase, LAPase and APase, respectively. The kinetic parameters $\left(V_{\max }\right.$ and $K_{\mathrm{m}}$ ) of both the dissolved and total fractions of LAPase and APase were very similar throughout the water column, suggesting a similar origin for both dissolved and particulate EEA. Significant correlations of both dissolved and total EEA were found with prokaryotic metabolism and the POM pool. Based on the previous notion that the fraction of dissolved EEA is higher in particle-attached than in free-living microbes, our results suggest that microbial activity in the dark ocean occurs mainly on colloidal and particulate material. This is in agreement with recent genomic evidence. However, these colloidal and particulate materials are prone to disruption during the sampling process. Hence, more selective sampling techniques are needed to specifically collect these deep-water aggregates that probably represent hotspots of microbial activity in the deep ocean.
\end{abstract}

KEY WORDS: Dissolved extracellular enzymatic activity · Prokaryotic heterotrophic production · Particulate organic matter · Deep ocean

\section{INTRODUCTION}

Prokaryotes play a major role as biomass producers and transformers of dissolved organic matter (DOM) in the sea (Azam \& Cho 1987). Heterotrophic prokaryotes express extracellular enzymes (EE) to hydrolyze high molecular weight DOM into lower molecular weight (MW) compounds of $<600 \mathrm{MW}$, which is the MW threshold of DOM that can be taken up by prokaryotes (Weiss et al. 1991). 
Since the introduction of fluorescent substrate analogues (Hoppe 1983) to quantify potential extracellular enzymatic activity (EEA), this technique has been applied to a wide range of aquatic environments (Chrost 1989, Rath et al. 1993, Misic et al. 2006). However, most of these applications have been restricted to the euphotic zone and coastal seas (Sala et al. 2001, Zaccone et al. 2003, Williams \& Jochem 2006). Only a few EEA profiles are available for the whole water column of the open ocean (Koike \& Nagata 1997, Hoppe \& Ullich 1999, Baltar et al. 2009a).

The activity of EE in the dark ocean is likely related to the composition of sinking particulate organic matter (POM). Previous studies suggest that a substantial fraction of sinking POM is solubilized to DOM, fueling prokaryotic production in the meso- and bathypelagic zones (Cho \& Azam 1988). The observation that particulate organic carbon (POC) decreases faster with depth than prokaryotic carbon demand led to the formulation of the 'particle decomposition paradox' (Karl et al. 1988). Cho \& Azam (1988) proposed that the underlying reason for this is an over-expression of EE by the particle-associated prokaryotic community, which releases the EE into the particles. This overexpression of dissolved EE results in a loose hydrolysis-uptake coupling of cleavage products and consequently, to the potential release of these products into the surrounding water, eventually fueling free-living prokaryotes (Karner \& Herndl 1992, Smith et al. 1992, Azam \& Long 2001). Prokaryotic EE can be released into the environment by a suite of different processes, either actively by the prokaryotic cell or via grazing activity (Chrost 1991, Bochdansky et al. 1995, Karner \& Rassoulzadegan 1995), and remain active for an extended period (Wetzel 1991).

The importance of dissolved EE in material cycling in soils is widely recognized (McLaren \& Skujins 1967, Paul 1989, Dick \& Tabatabai 1992); however, less consensus exists about the relevance of dissolved enzymes in marine communities. Most EEA in the oceans has been found to be associated with prokaryotes (Hoppe 1983, Hoppe et al. 2002). Consequently, it has been assumed that only cell-associated EE are of ecological significance (Someville \& Billen 1983, Rego et al. 1985, Chrost \& Rai 1993). Nevertheless, significant dissolved EEA in the oceanic water column has been detected on macroscopic particles such as marine snow (Karner \& Herndl 1992, Smith et al. 1992, Müller-Niklas et al. 1994).

Based on the notion that particle-attached prokaryotes are releasing EE into their environment and hence, exhibiting a loose hydrolysis-uptake coupling, we hypothesized that the contribution of the dissolved to the total EEA should be higher in the dark open ocean if deep-water prokaryotes are more dependent on POM as a substrate than surface-water prokaryotic communities. Heterotrophic microbial communities in surface waters have access to bioreactive DOM, while those in deep waters are in an environment where essentially all of the bulk DOM is refractory (Benner et al. 1992, Aluwihare et al. 2005).

In the present study, we investigated the dynamics of both total and dissolved EEA across the (sub)tropical Atlantic from the lower euphotic zone to the bathyand abyssopelagic layers (to $7000 \mathrm{~m}$ depth). We determined the EEA of 2 glycolytic enzymes ( $\alpha$-glucosidase and $\beta$-glucosidase), 1 proteolytic enzyme (leucine aminopeptidase) and alkaline phosphatase, and related them to prokaryotic abundance (PA) and heterotrophic production (PHP), as well as to the distribution of POC and particulate organic nitrogen (PON). We provide evidence that prokaryotic metabolism is related to the concentration of the POM pool and to the dissolved and total EEA, suggesting that colloidal and particulate organic matter might be more important for deep-water prokaryotes than hitherto assumed.

\section{MATERIALS AND METHODS}

Study site and sampling. EEA, heterotrophic prokaryotic biomass production and the concentration of POM were determined in several waters masses of the (sub)tropical Atlantic Ocean. The cruise track covered $>4500 \mathrm{~km}$ along an eastern zonal transatlantic (TA) transect (from Brazil through the Romanche Fracture Zone [RFZ], a major canyon in the Mid-Atlantic Ridge at the equator) and a western $\mathrm{N}-\mathrm{S}$ transect (roughly parallel to the African continental slope, African) (Fig. 1). Sampling from several depths, targeting the core of the main water masses, was done from the RV 'Pelagia' at 20 out of 30 stations occupied during the ARCHIMEDES-III cruise (December 2007 to January 2008). Along the TA transect, samples were obtained from the base of the mixed layer (subsurface, $100 \mathrm{~m}$ layer), the oxygen minimum layer (OML; consisting of South Atlantic Central Water), the Antarctic Intermediate Water (AAIW), the Upper North Atlantic Deep Water (UNADW), the Middle North Atlantic Deep Water (MNADW), the Lower Northeast Atlantic Deep Water (LNEADW), and the Antarctic Bottom Water (AABW). In the RFZ, the NADW and AABW mix and form transitional waters (Trans), since the RFZ is sufficiently deep to allow significant eastward flow of the AABW. The AABW slowly transforms to the Lower Deep Water (LDW) by mixing with the NEADW (Ferron et al. 1998). Along the N-S African transect, samples were taken from the subsurface, the OML (consisting of North and South Atlantic Central Water), the Sub-Arctic Intermediate Water (SAIW), the Upper 


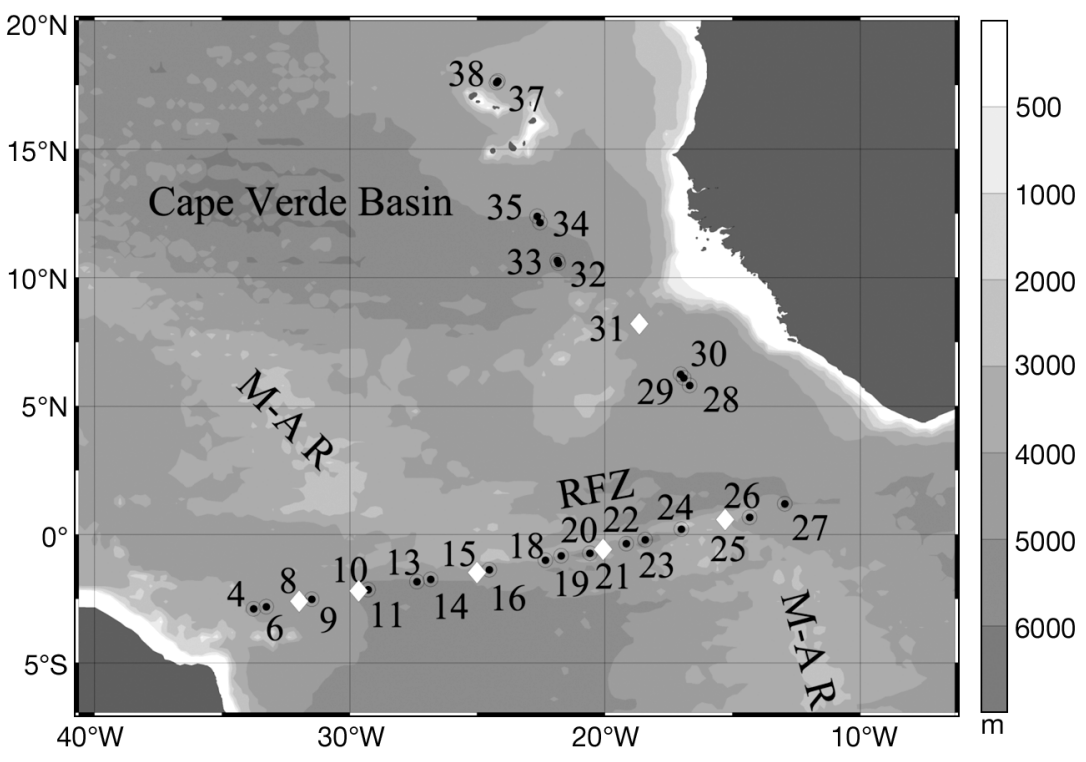

Fig. 1. Stations occupied during the ARCHIMEDES-III cruise. Numbered dots: sampled stations; open diamonds: stations where kinetic profiles were performed. The Transatlantic transect ranged from Stns 4 to 27, the African transect from Stns 28 to 38. M-A R: Mid-Atlantic Ridge, RFZ: Romanche Fracture Zone

Northeast Atlantic Deep Water (UNEADW), the NEADW, and the LDW. The specific water masses were identified based on their distinct temperaturesalinity characteristics and oxygen content (Table 1). Samples from the distinct water masses were collected using 121 Niskin bottles that were mounted on a CTD frame to determine total prokaryotic abundance and heterotrophic production, POM, and EEA as described below.

PA determination by flow cytometry. Prokaryotic plankton that were collected from the different depth layers of the water column were enumerated using flow cytometry. Samples $(2 \mathrm{ml})$ were fixed with $1 \%$ paraformaldehyde (final concentration), shock-frozen in liquid nitrogen for $5 \mathrm{~min}$ and stored at $-80^{\circ} \mathrm{C}$. Picoplankton cells were stained with SYBR-Green I and enumerated on board using a flow cytometer (FACSCalibur, Becton Dickinson) within $2 \mathrm{~d}$. Immediately before analysis, the thawed picoplankton samples were stained with SYBR-Green I (using a final concentration of $1 \times$ as recommended by the manufacturer) at room temperature in the dark for 15 min. Fluorescent microspheres (Molecular Probes) with a diameter of $1 \mu \mathrm{m}$ were added to all samples as an internal standard. Counts were performed using an argon laser that was set at $488 \mathrm{~nm}$ wavelength. Prokaryotic cells were enumerated according to their right angle scatter and green fluorescence. The counting window of the flow cytometer was set to exclude eukaryotic plankton.

PHP measurement by $\left[{ }^{3} \mathrm{H}\right]$-leucine incorporation. Bulk PHP was measured by incubating triplicate 10 to $40 \mathrm{ml}$ samples and triplicate formaldehyde-killed blanks ( $2 \%$ final concentration) with $5 \mathrm{nmol} \mathrm{l^{-1 }}\left[{ }^{3} \mathrm{H}\right]-$

Table 1. Characteristics of the main water masses sampled during the ARCHIMEDES-III cruise based on CTD profiles at individual stations. Ranges are given for each water mass where samples were collected. TA: Transatlantic, OML: oxygen minimum layer, AAIW: Antarctic Intermediate Water, UNADW: Upper North Atlantic Deep Water, MNADW: Middle North Atlantic Deep Water, LNADW: Lower North Atlantic Deep Water, Trans: Transitional water, AABW: Antarctic Bottom Water, SAIW: Sub-Arctic Intermediate Water, UNEADW: Upper Northeast Atlantic Deep Water, NEADW: Northeast Atlantic Deep Water, LDW: Lower Deep Water

\begin{tabular}{|llcccc|}
\hline Transect & Water mass & $\begin{array}{c}\text { Depth } \\
(\mathrm{m})\end{array}$ & $\begin{array}{c}\text { Temperature } \\
\left({ }^{\circ} \mathrm{C}\right)\end{array}$ & $\begin{array}{c}\text { Salinity } \\
\left(\mu \mathrm{mol} \mathrm{kg}{ }^{-1}\right)\end{array}$ \\
\hline TA & Subsurface & 100 & $14.1-23.7$ & $35.4-37$ & $89.2-199.1$ \\
& OML & $250-750$ & $4.6-13.7$ & $34.4-35.4$ & $74-152.6$ \\
& AAIW & $750-1200$ & $4.2-5.0$ & $34.4-34.6$ & $125.7-176.4$ \\
& UNADW & 1750 & $3.5-3.8$ & 34.9 & $206.8-247.6$ \\
& MNADW & $2750-3750$ & $2.1-2.6$ & 34.9 & $209.9-222$ \\
& LNADW & $3750-4500$ & $1.7-2.1$ & $34.8-34.9$ & $211.3-225.2$ \\
& Trans & $2750-4350$ & $1.2-2.6$ & $34.8-34.9$ & $204.5-212-9$ \\
& AABW & $4500-7150$ & $0.6-0.9$ & 34.7 & $190.1-199.9$ \\
African & Subsurface & 100 & $13.3-19.1$ & $35.3-36.7$ & $66.8-125.3$ \\
& OML & $250-470$ & $9.9-13.6$ & $34.7-35.4$ & $33.9-69.5$ \\
& SAIW & 750 & $6.0-7.3$ & 34.9 & $69.4-83$ \\
& UNEADW & 1750 & $1.8-3.8$ & 34.9 & $190.7-201-1$ \\
& NEADW & 2750 & $1.8-2.7$ & 34.9 & $207-209$ \\
& Trans & 3750 & $1.8-2.1$ & $34.8-34.9$ & $205.7-208$ \\
& LDW & $3400-5200$ & $1.6-2.3$ & $199.2-207.2$ \\
& & & &
\end{tabular}


leucine (final concentration, specific activity $160 \mathrm{Ci}$ $\mathrm{mmol}^{-1}$; Amersham) in temperature-controlled incubators in the dark at in situ temperature for 4 to $10 \mathrm{~h}$. Incubations were terminated by adding formaldehyde ( $2 \%$ final concentration) $10 \mathrm{~min}$ prior to filtering the samples and the blanks through $0.2 \mu \mathrm{m}$ polycarbonate filters (25 mm filter diameter, Millipore) supported by HAWP filters (Millipore, $0.45 \mu \mathrm{m}$ pore size). Subsequently, the filters were rinsed $3 \times$ with $5 \%$ ice-cold trichloroacetic acid, dried, and placed in scintillation vials. Scintillation cocktail (8 ml Canberra-Packard Filter Count) was added, and after $18 \mathrm{~h}$, counted in a liquid scintillation counter (LKB Wallac model 1212) on board. The mean disintegrations per minute (DPM) of the formaldehyde-fixed blanks were subtracted from the mean DPM of the respective samples and the resulting DPM converted to leucine incorporation rates. Prokaryotic carbon biomass production was estimated using a conservative theoretical conversion factor of $1.55 \mathrm{~kg} \mathrm{C} \mathrm{mol}^{-1}$ Leu assuming no internal isotope dilution (Kirchman \& Ducklow 1993). Average cell-specific leucine incorporation rates (fmol C cell ${ }^{-1}$ $\mathrm{d}^{-1}$ ) were calculated by dividing bulk leucine incorporation by prokaryotic abundance.

POC and PON. Samples (4 to $6 \mathrm{l}$ ) for POC and PON were filtered through combusted $\left(450^{\circ} \mathrm{C}\right.$ for $12 \mathrm{~h}$ ) $25 \mathrm{~mm}$ Whatman GF/F. The filters were wrapped in combusted aluminum foil and kept frozen at $-20^{\circ} \mathrm{C}$ until processed. In the laboratory, the filters were thawed and dried overnight at $65^{\circ} \mathrm{C}$ in a desiccator under $\mathrm{HCl}$ fumes to remove carbonates and finally, dried overnight in a desiccator with silica gel. Prior to analysis, samples were packed into ultraclean tin caps. Carbon analyses were performed on a CHN elemental analyzer (Perkin-Elmer 2400) according to the JGOFS (Joint Global Ocean Flux Study) protocol (UNESCO 1994). Concentrations of POM originating from lowvolume filtrations may be biased due to the possible sorption of DOM on the filter material (Moran et al. 1999). Hence, sorption blanks were determined for each station by placing 2 Whatman GF/F on top of each other in the filter holder while filtering the water sample. The adsorbed organic $\mathrm{C}$ and $\mathrm{N}$ collected by the lower filter was measured as described above and subtracted from the POC and PON content of the corresponding particulate sample.

Measurement of prokaryotic EEA. The hydrolysis of the fluorogenic substrate analogues 4-methylcoumarinyl-7-amide (MCA)-L-leucine-7-amido-4-methylcoumarin, 4-methylumbelliferyl (MUF)- $\alpha$-D-glucoside, 4-MUF- $\beta$-D-glucoside and MUF-phosphate was measured to estimate potential activity rates of leucine aminopeptidase (LAPase), $\alpha-, \beta$-glucosidase (AGase, BGase), and alkaline phosphatase (APase), respectively (Hoppe 1983). All chemicals were obtained from Sigma and appropriate stocks were prepared in methyl-cellosolve. The activity of the enzymes is linearly related to the fluorescence resulting from the hydrolytic cleavage of the monomer from MUF or MCA and was detected spectrofluorometrically using a fluorometer (Fluorolog-3) with a microwell plate reader (MicroMax 384, Horiba) at excitation and emission wavelengths of 365 and $445 \mathrm{~nm}$. Samples $(300 \mu \mathrm{l})$ were incubated in the dark at in situ temperature for $24 \mathrm{~h}$. The linearity of the increase in fluorescence over time was checked on sets of samples that were incubated for 24 to $48 \mathrm{~h}$, resulting in the same hydrolytic rates $\mathrm{h}^{-1}$. Subsamples without substrate were used as blanks to determine the background fluorescence of the samples. Previous experiments showed that abiotic hydrolysis of the substrates was not significant (data not shown). The fluorescence obtained at the beginning and at the end of the incubation was corrected for the corresponding blank. This increase in fluorescence over time was transformed to hydrolysis activity using a standard curve that was established, with different concentrations of the fluorochromes MUF and MCA being added to $0.2 \mu \mathrm{m}$ filtered sample water. To determine enzyme kinetics, model substrate concentrations should cover a sufficiently wide range. Twelve different concentrations were used for the different substrates, ranging from 0.39 to $800 \mu \mathrm{mol} \mathrm{l}^{-1}$ for APase and 0.98 to $2000 \mathrm{mmol} \mathrm{l}^{-1}$ for LAPase. For routine measurements, a final concentration of $10 \mu \mathrm{mol} \mathrm{l}^{-1}$ was applied to measure AGase and BGase activities, $100 \mu \mathrm{mol} \mathrm{l}^{-1}$ for APase and $500 \mu \mathrm{mol} \mathrm{l}^{-1}$ for LAPase. These concentrations have been previously determined as the saturating concentrations. Consequently, this approach yields potential hydrolysis rates.

Profiles of enzyme kinetics for APase and LAPase were determined at each station. The saturation curves were transformed into a Lineweaver-Burk or HanesWoolf plot to reveal maximum enzyme activity ( $V_{\text {max }}$ nmol $\mathrm{l}^{-1} \mathrm{~h}^{-1}$ ) and substrate affinity (Michaelis-Menten half-saturation constant; $K_{\mathrm{m}}, \mu \mathrm{mol} \mathrm{l^{-1 }}$ ).

We distinguished between the total EEA of the sample and the dissolved fraction of the EEA and their respective enzyme kinetics. For total EEA, raw seawater was used; for dissolved EEA, samples were filtered through a low protein binding $0.2 \mu \mathrm{m}$ Acrodisc Syringe filter (Pall), following the protocol of Kim et al. (2007). As suggested by these authors, gentle pressure was applied and care was taken to avoid exposing cells to the air at the end of the filtration (Nagata \& Kirchman 1990). As indicated by Obayashi \& Suzuki (2008), the adsorption of extracellular enzymes can be substantial depending on the filter used for size fractionation. The latter authors found that around half of the LAPase activity could be adsorbed onto mixed cellulose ester membrane filters (adsorption $>90 \%$ for trypsin and chymotrypsin) as compared to low protein binding filters. This adsorption of enzymes on 
filters would lead to an overestimation of the particulate EEA fraction. Also, extracellular enzymes may be washed off from the cell surface even during gentle filtration and thus contribute to the pool of dissolved enzymes. However, due to the low abundance of prokaryotes that are typically found in the deep ocean, the potential release of ectoenzymes is unlikely to contribute much to the pool of dissolved EEA. In the present study, dissolved EEA was considered as the EEA obtained in the filtrate. Total and dissolved EEA were determined on 6 replicate samples. For enzyme kinetics, 3 replicate samples were used.

Statistical analysis. Data were log transformed to attain normality prior to applying Student's $t$-test and Spearman's rank correlation. To check the normality of the individual data sets, the Kolmogorov-Smirnoff test was used. For calculating uncertainties in ratios, error propagation was taken into account; SDs were calculated using a formula for the propagation of error (Bevington \& Robinson 2003) as follows:

$$
\Delta z / z=\sqrt{ }\left[\left((\Delta x)^{2} / x\right)+\left((\Delta y)^{2} / y\right)\right]
$$

where $z$ is the resulting metabolic rate or kinetic parameter, which is equal to $x$ divided by $y$, as described in the formula. $\Delta x$ and $\Delta y$ are the SDs associated with $x$ and $y$, respectively. $\Delta z$ is the SD calculated for $z$. SDs were then converted to SEs for each calculation.

\section{RESULTS}

\section{PA and PHP}

As expected, PA decreased with depth by one order of magnitude (Fig. 2A) over the 100 to $7000 \mathrm{~m}$ depth range. Despite the fact that PA was higher in all the water masses of the African transect than along the TA transect, no significant differences were found between the average values of the 2 transects ( $t$-test; $\mathrm{p}=0.24, \mathrm{n}=139$ ). PHP also decreased with depth, although by 3 orders of magnitude (Fig. 2B), being only slightly higher in the subsurface and OML of the TA than of the African transect. Average cell-specific PHP decreased with depth by 2 orders of magnitude (Fig. 2C). Similar to PHP but contrasting with PA, average cell-specific PHP was only slightly higher in the subsurface and OML layers of the TA than of the African transect. As in PHP, no significant differences in average cell-specific PHP ( $t$-test; $\mathrm{p}>0.05$ ) were found in any of the water masses between the 2 transects.

\section{Distribution of POM}

POC (Fig. 3A) was significantly higher in all the water masses of the TA than in those of the African transect $(t$-test; $\mathrm{p}<0.001, \mathrm{n}=106)$. In the TA, POC increased by a factor of 2 from the $100 \mathrm{~m}$ depth layer to the AAIW, and decreased thereafter to concentrations similar to those of subsurface waters (Fig. 3A). In the African transect, however, POC concentrations decreased with depth from subsurface waters to the LNADW to about half of the subsurface POC concentration, and increased in the deepest water mass sampled (LDW) to POC concentrations similar to those of subsurface waters (Fig. 3A).

PON concentrations were generally 1 order of magnitude lower than POC concentrations (Fig. 3B), decreasing with depth in both transects. In contrast to POC, significantly higher ( $t$-test; $\mathrm{p}<0.05, \mathrm{n}=105$ )

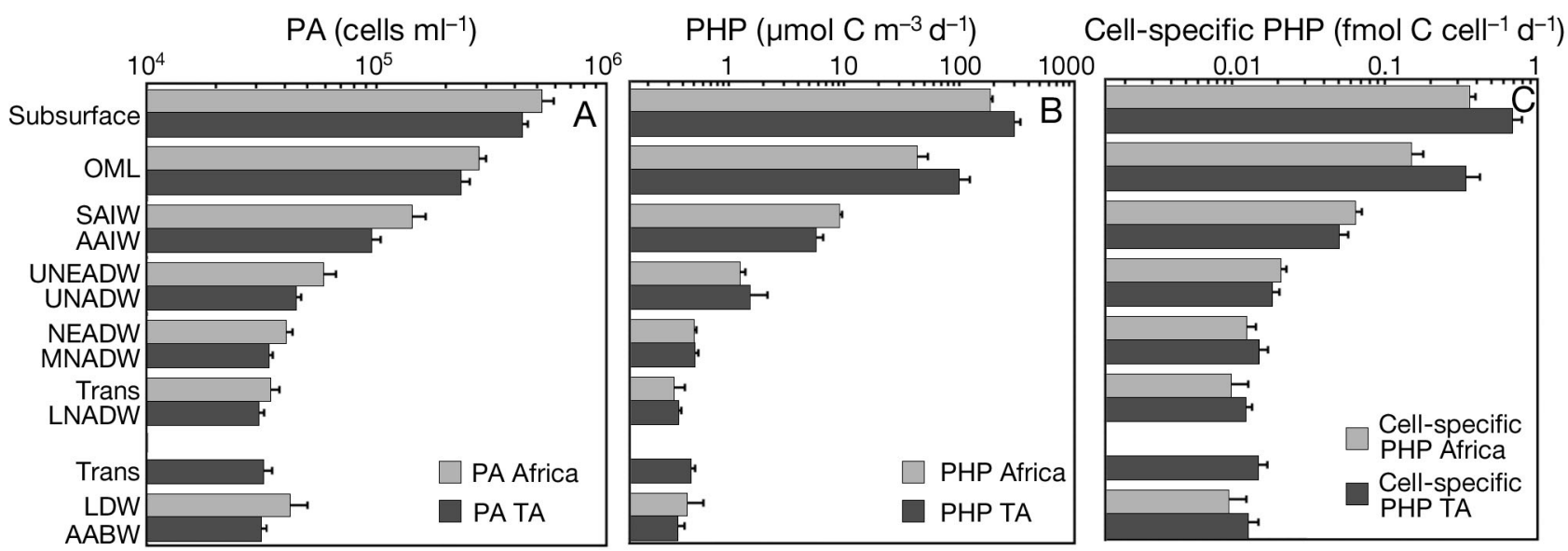

Fig. 2. Distribution of basic prokaryotic parameters in the different water masses in the Transatlantic (TA) and the African (Africa) transects (see Table 1 for the depth range of each water mass). (A) Prokaryotic abundance (PA, cells ml ${ }^{-1}$ ), (B) prokaryotic heterotrophic production (PHP, $\mu$ mol $\mathrm{C} \mathrm{m}^{-3} \mathrm{~d}^{-1}$ ), (C) average cell-specific PHP (fmol C cell ${ }^{-1} \mathrm{~d}^{-1}$ ). Error bars: SE. See Table 1 for water mass abbreviations 
PON concentrations were found along the African transect than along the TA transect (compare Fig. 3A \& B), albeit PON concentrations were similar in the deepest water masses (Trans, NADW, LDW and AABW) of the 2 transects ( $t$-test; $\mathrm{p}>0.05$ ). Throughout the entire water column, the mean $\mathrm{C}: \mathrm{N}$ ratio of POM (Fig. 3C) was significantly higher along the TA than along the African transect ( $t$-test; $\mathrm{p}<$ $0.0001, \mathrm{n}=105)$, due to both the higher POC and lower PON concentrations in the former than in the latter.

\section{Total and dissolved EEA}

In contrast to PHP, total and dissolved EEA decreased only slightly with depth (Fig. 4). The different total EEA were significantly correlated with each other $\left(\mathrm{r}_{\mathrm{S}}, \mathrm{p}<0.0001\right)$. A particularly strong correlation was found between AGase (Fig. 4A) and BGase (Fig. 4B) activities $\left(\mathrm{r}_{\mathrm{S}}=0.91, \mathrm{p}<0.0001, \mathrm{n}=106\right.$ ) (compare Fig. 4A \& B). Leucine aminopeptidase (LAPase; Fig. 4C) and alkaline-phosphatase (APase; Fig. 4D) activities were generally higher than those of AGase
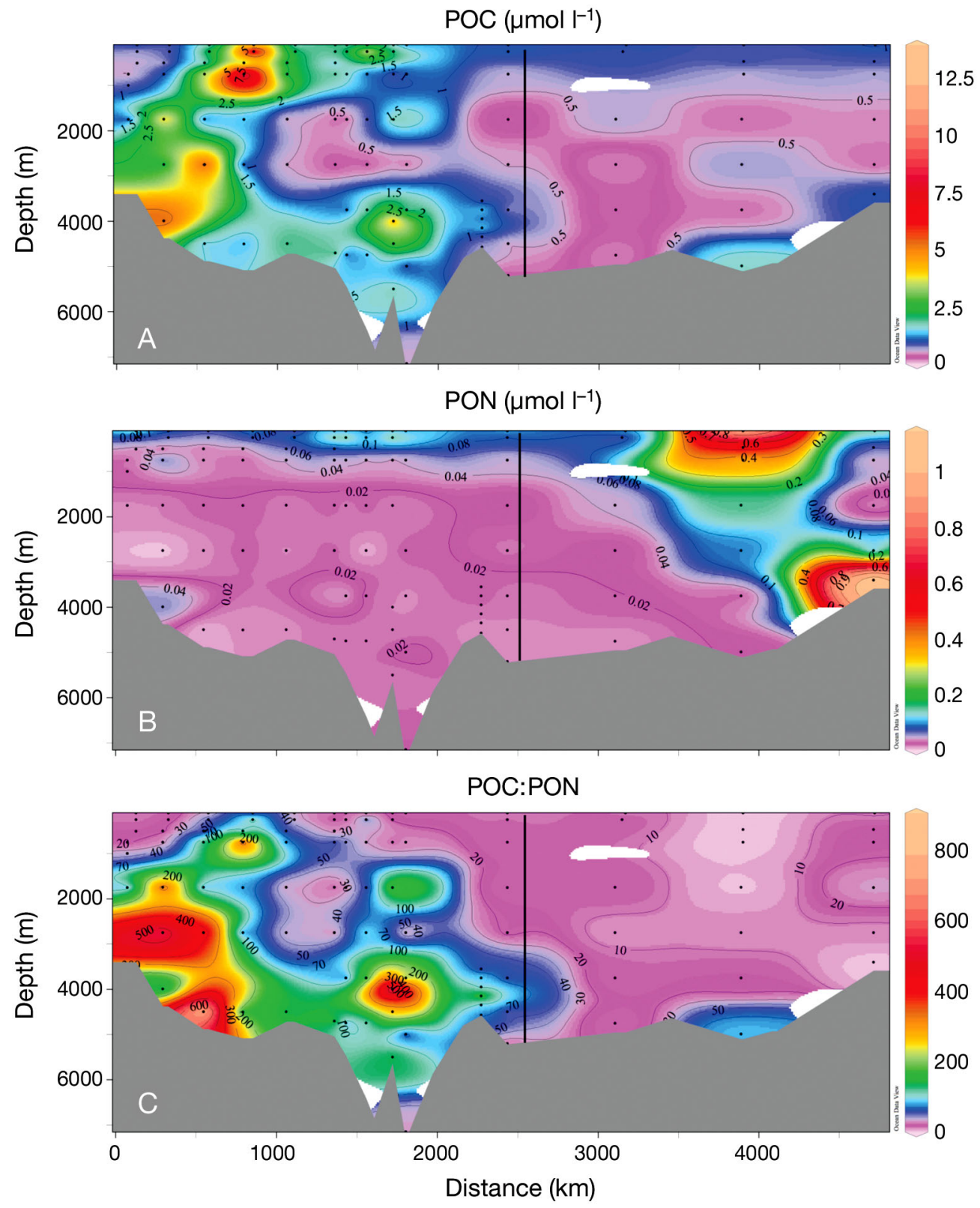

Fig. 3. Distribution of (A) POC (particulate organic carbon; $\mu \mathrm{mol} \mathrm{l}^{-1}$ ), (B) PON (particulate organic nitrogen; $\mu \mathrm{mol} \mathrm{l}^{-1}$ ), $(\mathrm{C})$ POC:PON molar ratios throughout the water column along the entire ARCHIMEDES-III cruise track (from Stns 4 to 38). Vertical line: where the cruise track turned from the westward (Transatlantic) to the northward (African) transect 

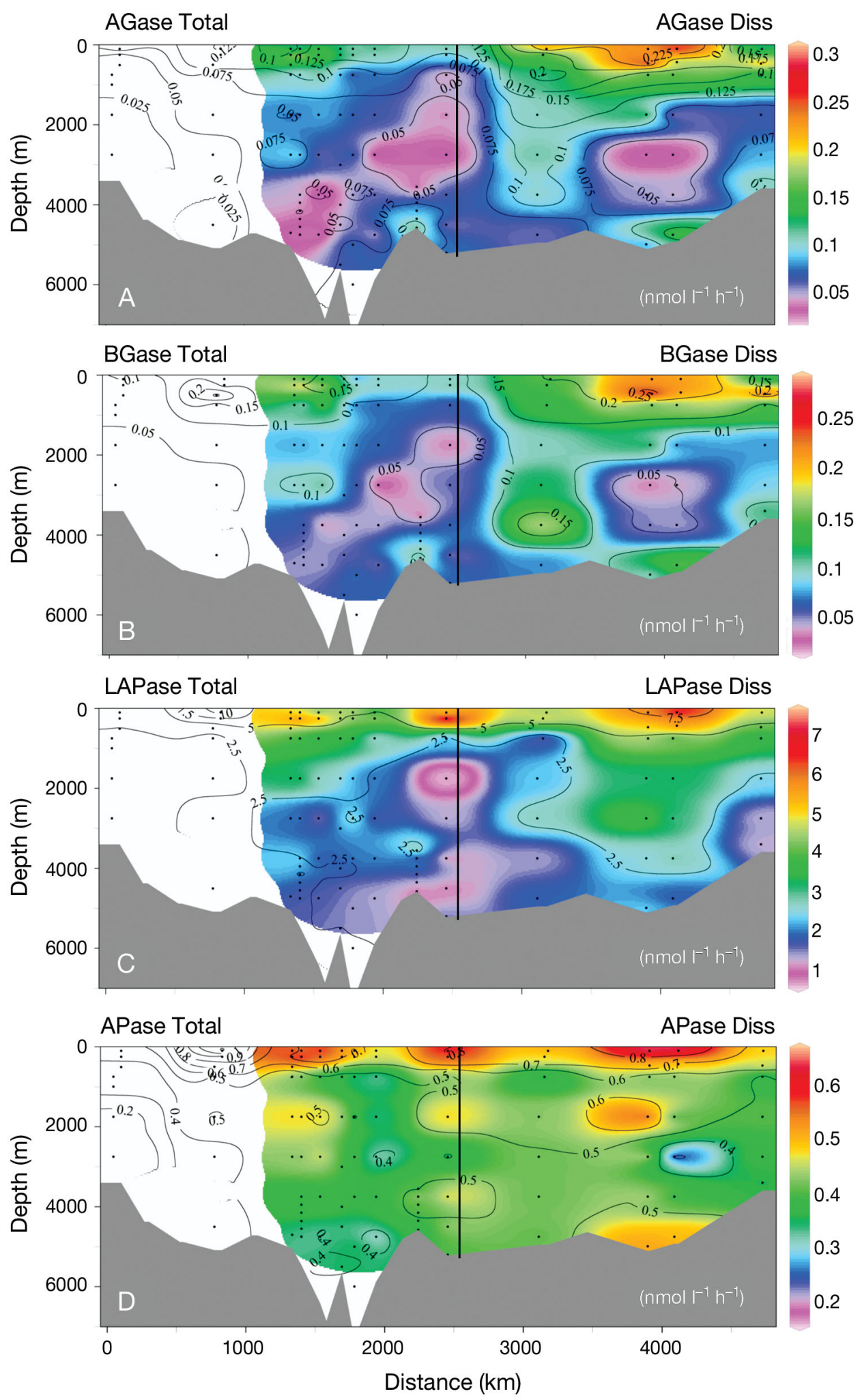

Fig. 4. Distribution of (A) AGase ( $\alpha$-glucosidase), (B) BGase ( $\beta$-glucosidase), (C) LAPase (leucine aminopeptidase) and (D) APase (alkaline phosphatase) activities throughout the water column along the entire ARCHIMEDES-III cruise track (from Stns 4 to 38); values are given in nmol $\mathrm{l}^{-1} \mathrm{~h}^{-1}$. Total extracellular enzymatic activities (EEAs) are plotted as black isolines over the dissolved EEAs (colour gradients). Where colour shades are missing, only total EEA was measured. Vertical line: boundary between the Transatlantic and the African transects. Diss: dissolved 
and BGase, particularly at the base of the euphotic layer (subsurface layer). APase activity decreased less with depth than the activities of AGase, BGase and LAPase.

As with total EEA, the different dissolved EEA were also significantly correlated with each other $\left(\mathrm{r}_{\mathrm{S}}, \mathrm{p}<\right.$ 0.0001). Again, the strongest correlation was found between dissolved AGase and BGase $\left(\mathrm{r}_{\mathrm{S}}=0.90, \mathrm{p}<\right.$ $0.0001, \mathrm{n}=66$ ). The distribution patterns of the dissolved and the total EEA for all the enzymes (AGase, BGase, LAPase and APase) were very similar along the cruise track and throughout the water column (compare black isolines with color background in Fig. 4A-D). Hence, the different total and dissolved EEA were correlated with each other $\left(r_{S}, p<0.005\right)$. The log-log slope of the dissolved versus total EEA was very close to 1 for AGase (slope $=0.98, \mathrm{n}=66, \mathrm{R}^{2}=$ 0.96), BGase (slope $=0.97, \mathrm{n}=66, \mathrm{R}^{2}=0.95$ ) and LAPase (slope $=0.93, n=66, R^{2}=0.98$ ), but lower for APase (slope $=0.75, n=66, R^{2}=0.85$ ). No significant differences in any of the EEA were detectable ( $t$-test; $p<0.05)$ between the African and the TA transects. Average cell-specific EEA increased with depth for all the enzymes (data not shown).

The contribution of the dissolved to the total EEA (Fig. 5A-D) was high in the aphotic layers for all enzymes, particularly for LAPase and APase (Fig. 5C,D), whereas the contribution of dissolved AGase and BGase to their respective total EEA was more patchy (Fig. 5A,B). Overall, no significant differences were found in the percentages of the dissolved to the total EEA for any of the enzymes between the 2 transects $(t$-test; $\mathrm{p}<0.05)$.

\section{Dynamics in the kinetics of total and dissolved LAPase and APase}

At 6 stations (diamonds in Fig. 1), profiles of kinetic parameters for total and dissolved LAPase and APase were obtained. Generally, the maximum hydrolysis rates $\left(V_{\max }\right)$ of total and dissolved LAPase and APase decreased with depth (Fig. 6A,B). Significant differences in the $V_{\max }$ of total and dissolved LAPase ( $t$-test; $\mathrm{p}<0.001, \mathrm{n}=29)$ and APase ( $t$-test; $\mathrm{p}<0.001, \mathrm{n}=30$ ) were found between the subsurface and OML and the deeper water masses. Significant differences in $V_{\max }$ between the dissolved and total fractions were only found in subsurface waters ( $t$-test; $\mathrm{p}=0.013, \mathrm{n}=10$ ) and in the OML ( $t$-test; $\mathrm{p}=0.048, \mathrm{n}=10$ ) for LAPase, and in the AAIW ( $t$-test; $\mathrm{p}=0.038, \mathrm{n}=10$ ) for APase. In these upper water masses, the differences in $V_{\max }$ between the dissolved and total fractions were higher for APase (Fig. 6B) than for LAPase (Fig. 6A). The detected difference in the $V_{\max }$ between dissolved and total APase coincided with the lower contribution of dissolved APase to the total APase pool as compared to that of LAPase (Fig. 4A-D).

In contrast to $V_{\max }$, the half-saturation constants $\left(K_{\mathrm{m}}\right)$ of the total and the dissolved fractions of LAPase increased with depth (Fig. 6C). The subsurface and OML exhibited significantly lower $K_{\mathrm{m}}$ than the deeper water masses for total $(t$-test; $\mathrm{p}=0.00013, \mathrm{n}=29)$ and dissolved ( $t$-test; $\mathrm{p}=0.0005, \mathrm{n}=29$ ) LAPase, and for total APase ( $t$-test; $\mathrm{p}=0.0004, \mathrm{n}=30$; Fig. 6D). As with $V_{\text {max }}$ the difference in $K_{\mathrm{m}}$ between the total and the dissolved fractions was higher for APase (Fig. 6D) than for LAPase (Fig. 6C), particularly in the 2 upper water masses. Significant differences in $K_{\mathrm{m}}$ between the dissolved and the total fractions were only found for APase in the OML $(t$-test; $\mathrm{p}<0.05, \mathrm{n}=10)$.

\section{DISCUSSION}

Only a few reports on EEA in deep oceanic water columns are available. Our range of LAPase activities ( 0.2 to $\left.13.8 \mathrm{nmol} \mathrm{l}^{-1} \mathrm{~h}^{-1}\right)$ is similar to that reported for the water column (100 to $4500 \mathrm{~m}$ ) of the (sub)tropical North Atlantic (0.6 to $9.2 \mathrm{nmol} \mathrm{l}^{-1} \mathrm{~h}^{-1}$; Baltar et al. 2009a), for the deep Indian Ocean (6 to $15 \mathrm{nmol} \mathrm{l}^{-1} \mathrm{~h}^{-1}$; Hoppe \& Ullrich 1999) and for the Tyrrhenian Sea down to $3500 \mathrm{~m}$ depth $\left(0.51\right.$ to $8.6 \mathrm{nmol} \mathrm{l}^{-1} \mathrm{~h}^{-1}$; Tamburini et al. 2009). Our LAPase rates, however, are higher than those reported in other studies such as those in the Mediterranean Sea down to $2000 \mathrm{~m}$ depth ( 0.034 to 2.77 and 0.23 to $1.78 \mathrm{nmol} \mathrm{l}^{-1} \mathrm{~h}^{-1}$; Zaccone et al. 2003 and Tamburini et al. 2002, respectively). The APase activities reported in this study (0.14 to $1.3 \mathrm{nmol}$ $\mathrm{l}^{-1} \mathrm{~h}^{-1}$ ) are also in the same range as those reported for the (sub)tropical Atlantic water column (0.04 to $3.7 \mathrm{nmol} \mathrm{l}^{-1} \mathrm{~h}^{-1}$; Baltar et al. 2009a), for the DYFAMED station (0.01 to $1.8 \mathrm{nmol} \mathrm{l}^{-1} \mathrm{~h}^{-1}$; Tamburini et al. 2002) and for the Tyrrhenian Sea $\left(0.21\right.$ to $9.9 \mathrm{nmol} \mathrm{l}^{-1} \mathrm{~h}^{-1}$; Tamburini et al. 2009), but lower than the rates obtained for Indian Ocean deep waters (2 to $4.5 \mathrm{nmol}$ $\mathrm{l}^{-1} \mathrm{~h}^{-1}$; Hoppe \& Ullrich 1999), and higher than the rates reported for the Ionian Sea $\left(0.08\right.$ to $0.4 \mathrm{nmol} \mathrm{l}^{-1}$ $\mathrm{h}^{-1}$; Zaccone et al. 2003) and for the central Pacific deep waters ( 0.031 to $0.35 \mathrm{nmol}^{-1} \mathrm{~h}^{-1}$; Koike \& Nagata 1997). However, the latter study only measured the particulate fraction of APase $(>0.2 \mu \mathrm{m})$, which might explain the low values reported by these authors.

Although it has been assumed that only cell-associated EE are of ecological significance (Someville \& Billen 1983, Rego et al. 1985, Chrost \& Rai 1993), the contribution of dissolved EEA to the total EEA (AGase, BGase, LAPase and APase) measured in this study was high in the dark open ocean, reaching almost $100 \%$ (Fig. 5A-D). Several studies have addressed the 


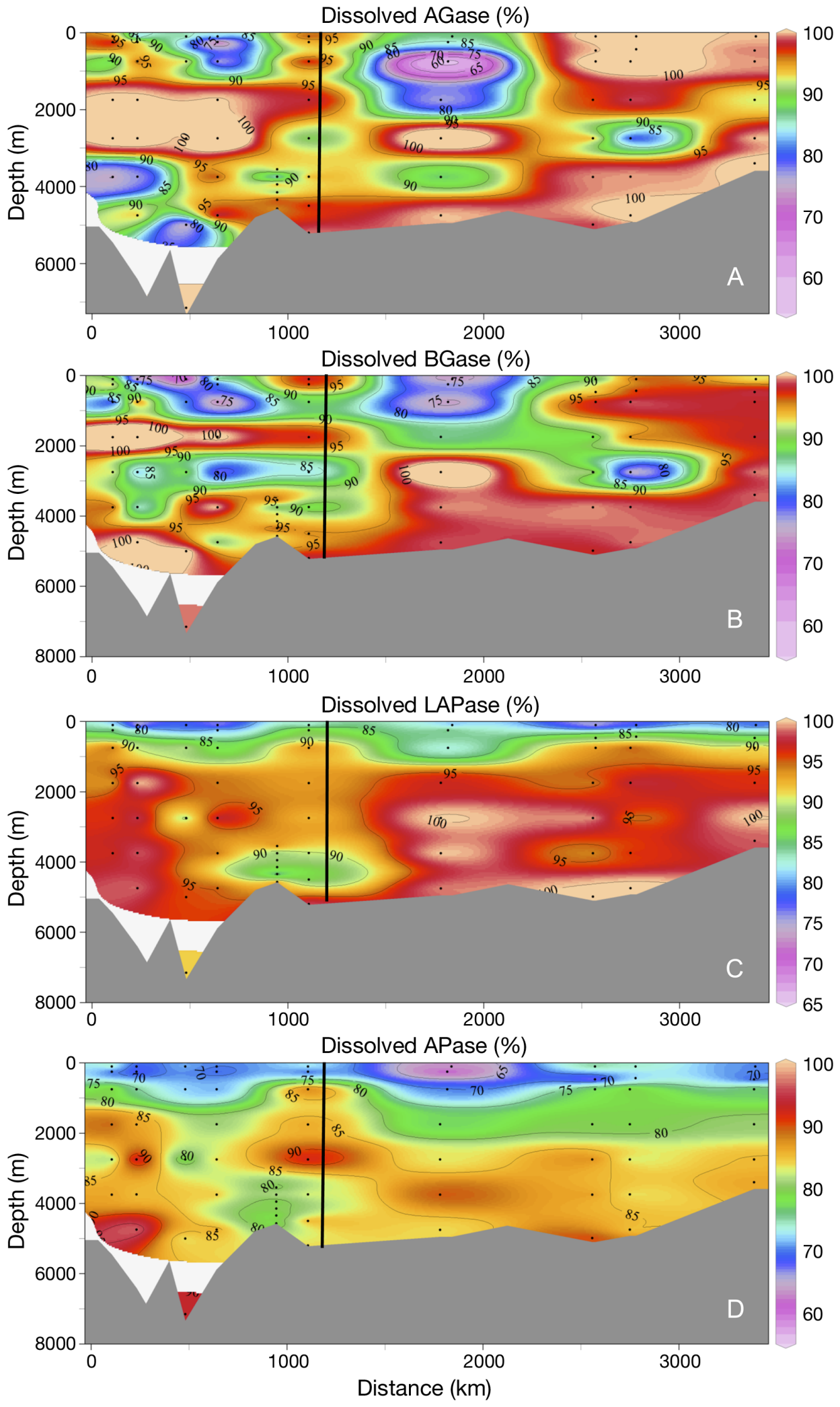

Fig. 5. Distribution of the percentages of dissolved relative to the total (A) AGase ( $\alpha$-glucosidase), (B) BGase ( $\beta$-glucosidase), (C) LAPase (leucine aminopeptidase) and (D) APase (alkaline phosphatase) activities throughout the water column along the entire ARCHIMEDES-III cruise track (from Stns 18 to 38). Note that panels start at Stn 18 because no measurements of dissolved EEA were performed between Stns 4 and 18 (see Fig. 4). Vertical line: boundary between the Transatlantic and the African transect. SEs were $\sim 9,10,2$ and $3 \%$ for AGase, BGase, LAPase and APase, respectively 
importance of dissolved EEA to total hydrolytic activity. Someville \& Billen (1983) reported that most of the exoprotease activity in the eutrophic Belgian coastal waters was in the dissolved fraction. In Tokyo Bay, dissolved carboxypeptidase activity contributed between 10 and $50 \%$ of the total EEA, both in freshwater and seawater communities (Hashimoto et al. 1985). In the Adriatic Sea, over a time-course of $22 \mathrm{~h}$, dissolved $\alpha$ and $\beta$-glucosidase activity reached 73 and $65 \%$ of the activity in unfiltered water, respectively (Bochdansky et al. 1995). Over a diel cycle at a coastal site in the western Mediterranean Sea, dissolved AGase and BGase activities ranged between 0 and $100 \%$ of total activities (Karner \& Rassoulzadegan 1995). Free laminarinase activity contributed up to $100 \%$ of total lami- narin and 48 to $69 \%$ of total xylan hydrolysis in a mesocosm experiment during a phytoplankton bloom (Keith \& Arnosti 2001). In the Elbe Estuary, Karrasch et al. (2003) reported that the dissolved EEA reached 20 to $80 \%$ of the total water column activity. Ziervogel \& Arnosti (2008) who studied the EEA of surface waters in the northeastern Gulf of Mexico concluded that dissolved EEA plays a significant role in the hydrolysis of high-molecular weight substrates. All the above studies highlight the major contribution of dissolved EE to total hydrolytic activity, despite its variability in time and space. Nevertheless, none of these studies addressed the importance of dissolved EEA with respect to total EEA throughout the entire water column of the open ocean, and in particular the deep sea.
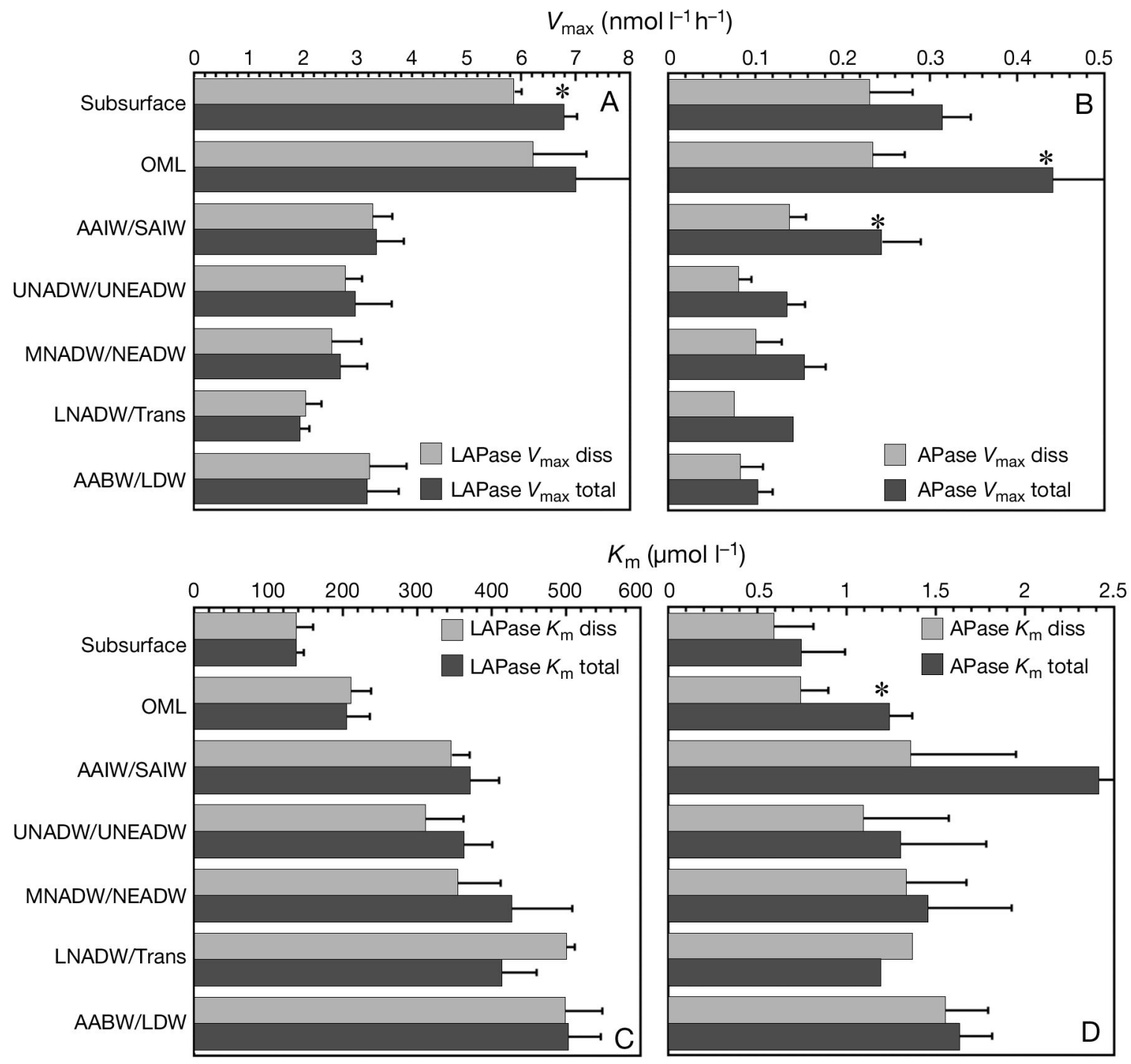

Fig. 6. Extracellular enzymatic kinetics of LAPase (leucine aminopeptidase; A,C) and APase (alkaline phosphatase; B,D) at the stations identified in Fig. 1: (A,B) maximum enzyme activities $\left(V_{\max }, \mathrm{nmol} \mathrm{l}^{-1} \mathrm{~h}^{-1}\right),(\mathrm{C}, \mathrm{D})$ Michaelis-Menten half-saturation con-

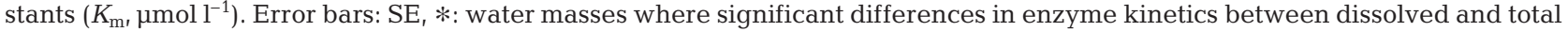
extracellular enzymatic activities (EEAs) were measured. See Table 1 for water mass abbreviations. diss: dissolved 
In the only profile available that compared dissolved and total EEA in the ocean, Davey et al. (2001) found that total potential LAPase rates significantly decreased with depth (0 to $200 \mathrm{~m}$ depth) while dissolved LAPase did not. Thus, the contribution of dissolved LAPase increased towards the deeper waters. Our results are in agreement with the EEA profile reported by Davey et al. (2001), but extended the findings to the bathy- and abyssopelagic realm.

This rather high contribution of dissolved to the total EEA is surprising, as it is commonly assumed that freeliving prokaryotes exhibit a tight hydrolysis-uptake coupling with the ectoenzymes attached to the cell wall or in the periplasmic space, where hydrolysis of macromolecular substrate occurs in intimate vicinity to the sites of hydrolysis product uptake (Hoppe et al. 2002). In contrast, particle-associated prokaryotes have been suggested to exhibit a loose hydrolysis-uptake coupling with the extracellular enzymes released into the particle. Enzymatic cleavage of substrate can thus occur at some distance from the cell (Smith et al. 1992). Vetter \& Deming (1999) reported that released bacterial EE could produce sufficient hydrolysate from POC to support growth in the absence of any other significant source of DOC and without direct contact between the cell and particulate substrate. These empirical results obtained by Vetter \& Deming (1999) support the model-based predictions formulated in an earlier paper (Vetter et al. 1998), suggesting that dissolved EE are advantageous when bacteria are attached to particles and when the substrate is within a well-defined distance from the enzyme source.

The factors determining the contribution of dissolved to the total EEA are not well understood. Investigations on pure cultures of bacteria have demonstrated that EE can be released from cells in the presence of the corresponding substrate (Alderkamp et al. 2007), as a function of the growth phase (Antranikian 1992), in response to bacterial starvation (Albertson et al. 1990), viral lysis (Karner \& Rassoulzadegan 1995), protozoan grazing (Bochdansky et al. 1995), or changes in microbial cell permeability (Chrost 1991). Once EE are released, they will remain active for a certain period. However, the lifetime of dissolved EE in marine waters is largely unknown, and different enzymes seem to have different hydrolytic lifetimes. In an enzyme degradation experiment, Bochdansky et al. (1995) found that $\sim 70 \%$ of the initial dissolved AGase and BGase activities remained after $22 \mathrm{~h}$. Ziervogel \& Arnosti (2008) showed that free laminarinase was highly active only in the initial phase of a $144 \mathrm{~h}$ incubation, whereas xylanase, pullulanase and chondroitin hydrolase were active throughout the entire incubation period.
There are 2 possible reasons for the high dissolved EEA in the deep ocean. Either the dissolved EE are a consequence of the substrate history of the water masses, or they are actively released by prokaryotes. The first option would depend on passive advection of the dissolved EEA by horizontal and vertical transport. No autochthonous release of EE would then be required, as the dissolved EE would be generated elsewhere. However, this would require that the dissolved EE remain active for a prolonged period. The lifetime of free enzymes has been shown to be extended if they are associated with particles (Gianfreda \& Scarfi 1991, Ziervogel et al. 2007). Koike \& Nagata (1997; deep central Pacific) and Kim et al. (2007; benthic nepheloid layer of a mesotrophic lake) suggested that the high APase activity coinciding with high phosphate concentrations might be due to the transport of these enzymes that are attached to rapidly sinking particles from the euphotic zone and their subsequent fragmentation and dissolution. It is known that surface associations may offer dissolved EE an improved resistance to physicochemical degradation (Lähdesmäki \& Piispanen 1992), and protection from remineralization (Lozzi et al. 2001). There is also evidence that bacterial EE can be embedded in an exopolymeric matrix (Decho 1990). Dissolved EE may become attached to this matrix and form a complex similar to the enzyme-humic complexes in soils (Chrost 1990). Another potential mechanism for the incorporation of EE into detrital particle complexes would be the trapping of digestive enzymes within partially degraded bacterial membranes which act as micelles (liposomes) (Nagata \& Kirchman 1992). A large fraction of the dissolved EE may be trapped by particles including colloids or liposomes. Furthermore, the additional stabilizing effects of low temperatures that are characteristic of the deep ocean could also facilitate the preservation of dissolved EE in the deep ocean as compared to shallow waters. The discontinuities shown by EEA in the vertical profiles (Fig. 6) further suggest signals of advective water transport.

The kinetic parameters $\left(V_{\max }\right.$ and $K_{\mathrm{m}}$ ) for LAPase and APase determined in this study (Fig. 6A-D) are in the same range as those obtained in a previous Atlantic study (Baltar et al. 2009a), which is the only other study where kinetic parameters have been determined throughout the whole oceanic water column. As in the present study, Baltar et al. (2009a) reported a decrease in the $V_{\max }$ of LAPase $\left(\sim 12\right.$ to $\left.3 \mathrm{nmol} \mathrm{l}^{-1} \mathrm{~h}^{-1}\right)$ and APase $\left(\sim 0.3\right.$ to $\left.0.1 \mathrm{nmol}^{-1} \mathrm{~h}^{-1}\right)$ and an increase in the $K_{\mathrm{m}}$ of LAPase $(\sim 400$ to $1200 \mu \mathrm{M})$ and APase ( 2 to $23 \mu \mathrm{M})$ with depth down to $4500 \mathrm{~m}$. Tamburini et al. (2002) obtained lower $K_{\mathrm{m}}$ values (ranging between 0.4 and $1.1 \mu \mathrm{M})$ for LAPase in the Mediterranean deep-waters (down to $2000 \mathrm{~m}$ depth) than in the present study. However, the APase $K_{\mathrm{m}}$ values (0.05 to $\left.1.2 \mu \mathrm{M}\right)$ 
reported by Tamburini et al. (2002) are in the same range as the APase $K_{\mathrm{m}}$ we obtained. In contrast to Tamburini et al. (2002), but in agreement with Baltar et al. (2009a) and with the present study, Davey et al. (2001) reported increasing total LAPase $K_{\mathrm{m}}$ values with depth, from $\sim 70 \mu \mathrm{M}$ in surface waters to $250 \mu \mathrm{M}$ at $200 \mathrm{~m}$ depth in the North Atlantic. In the latter study; however, dissolved LAPase $K_{\mathrm{m}}$ was between 500 to $3000 \mu \mathrm{M}$ with no depth-related trend. These authors also found a significant decrease in the total LAPase $V_{\max }$ with depth but not in the dissolved $V_{\text {max }}$. The differences between the LAPase $K_{\mathrm{m}}$ obtained by Tamburini et al. (2002) and the other studies including the present one could be due to the fact that Tamburini et al. (2002) added substantially lower substrate concentrations $(0.05$ to $5 \mu \mathrm{M})$. The same distribution pattern with depth (decrease in $V_{\max }$ and increase in $K_{\mathrm{m}}$ ) as reported in the present study was found by Davey et al. (2001) and by Baltar et al. (2009a). The increase in $K_{\mathrm{m}}$ and in the cell-specific $V_{\max }: K_{\mathrm{m}}$ ratio (which describes the ability of enzymes to compete at low substrate concentrations; Healey 1980) with depth is most likely due to the refractory nature of the organic matter present in deep waters. The high $K_{\mathrm{m}}$ found in the deep ocean for the 2 enzymes (Fig. 6C-D) might also suggest that the bulk of deep-water prokaryotes are subjected to a way of life that is dependent on pulses of organic matter supply. Hoppe et al. (1993) suggested that mesopelagic bacteria have the capability to respond or adapt rapidly to nutrient changes. Moreover, a substantially higher $V_{\max }$ than the actual uptake rates or turnover of the substrates has been previously reported (Hoppe et al. 1993, Davey et al. 2001). This might indicate substrate limitation or an excess of EE. The latter would allow prokaryotes to rapidly utilize pulses of substrates. As shown by the kinetic experiments (Fig. 6) and the contribution of dissolved EEA (Fig. 5), APase seems to be more particleassociated than LAPase. This could be explained if, as suggested by Koike \& Nagata (1997) and Kim et al. (2007), APase was more associated with solid sinking algal aggregates, which would not be as prone to destruction by filtration as gel-like particles. Overall, the fact that the kinetic parameters of total and dissolved EE are similar in the meso- and bathypelagic waters (Fig. 6A-D) suggests that dissolved and total EE are of the same origin, with dissolved EE not being advected from other areas.

A similar origin for dissolved and total EEA would support the second hypothesis explaining the observed dominance of dissolved EEA in the dark waters of the central Atlantic Ocean. Thus, EEA might result from autochthonous prokaryotic activity associated with fragile colloidal and particulate material, which are prone to be disrupted during sampling. It is well known that coagulation processes can lead to the formation of colloidal and ultimately, microparticulate organic material (Verdugo et al. 2004). Even lowmolecular weight DOM has the potential to coagulate spontaneously to form polymeric gels (Azam 1998, Chin et al. 1998). These microgels may interact with other colloidal matter, forming distinct submicrometer particles that are ubiquitously present in seawater at concentrations of up to $10^{9} \mathrm{ml}^{-1}$ (Koike et al. 1990, Wells \& Goldberg 1992, Wells 1998). This polysaccharide-based condensed matter harbors a higher concentration of nutrients than the surrounding water (Müller-Niklas et al. 1994). Bacteria have been reported to be enriched by up to 3 orders of magnitude on particles (Müller-Niklas et al. 1994). These would generate nutrient-enriched zones in the micrometer range, similar to the microzones proposed by Azam (1998). The above-cited papers (this paragraph), however, all dealt with colloidal and marine snow-type particles in the euphotic layer and upper mesopelagic realm. Whether this kind of particle also prevails in the deeper meso- and bathypelagic ocean is largely unknown. Recently, Verdugo et al. (2008) reported high concentrations of DOM polymers that were spontaneously forming bioreactive polymer gels in coastal and oceanic samples collected down to depths of $4000 \mathrm{~m}$. These recently discovered self-assembled microgels are extensively colonized by microbes. The concentration of these particles is estimated to be 10 to $50 \times$ larger than the total biomass of marine organisms, and could thus be among the richest pools of bioreactive carbon on our planet. Moreover, they could supply a major fraction of the microbial substrate, which could be particularly important in the deep ocean where substrate is limited.

In the present study, POM distribution was significantly different between the TA and the African transects (Fig. 3A-C), probably due to distinct oceanographic conditions (e.g. different water masses and circulation patterns, proximity to upwelling regions). However, along the 2 transects, POC concentrations were rather constant while PON decreased with depth (particularly in the TA transect), leading to higher POC:PON ratios in deeper layers. The observed stable distribution of POC with depth is in striking contrast to the generally observed decrease in sinking POC collected with sediment traps (Antia et al. 2001), and might reflect the potential of deep-water DOC to coagulate and form POC as proposed by Verdugo et al. (2008).

Thus, there is evidence that carbon-rich colloidal and/or particulate organic matter is abundant in the deep ocean. The release of EE into particles by particle-associated prokaryotes might help in maintaining relatively high metabolic activity as compared to their 
free-living counterparts. In fact, bacterial foraging theory suggests that independent of possible assemblage differences, individual bacteria may produce more EE in diffusionally constrained space such as particle aggregates, where the return of hydrolysate is potentially high (Vetter et al. 1998) or, when confronted with polymeric organic matter (Chrost 1991, Vetter \& Deming 1999). Moreover, Allison (2005) argued that microbes releasing EE have a competitive advantage over other microbes in environments with low rates of enzyme diffusion, such as sediments or particles.

To further investigate whether prokaryotes are associated with suspended particulate organic material in the deep ocean, prokaryotic metabolic activity was compared with the POM pool (Table 2). Significant correlations were found between the POM pool, PHP, and the dissolved and total EEA, as well as the contribution of dissolved to the total EEA for all the enzymes studied. PHP was correlated $\left(\mathrm{r}_{\mathrm{S}}, \mathrm{p}<0.002\right)$ with dissolved and total AGase, BGase, LAPase and APase (Table 2). The strongest correlations with PHP were found for APase (PHP to total APase: $r_{S}=0.67, p<$ 0.0001, $\mathrm{n}=93$; PHP to dissolved APase: $\mathrm{r}_{\mathrm{S}}=0.71, \mathrm{p}<$ $0.0001, \mathrm{n}=53$; PHP to \% of dissolved to total APase: $\mathrm{r}_{\mathrm{S}}$ $=-0.62, \mathrm{p}<0.0001, \mathrm{n}=53$ ), and for the contribution of dissolved to total LAPase $\left(\mathrm{r}_{\mathrm{S}}=-0.67, \mathrm{p}<0.0001, \mathrm{n}=\right.$ 53). Furthermore, POC was significantly correlated $\left(\mathrm{r}_{\mathrm{S}}\right.$ $\mathrm{p}<0.0001$ ) with the 4 dissolved and total EEA, and with the contribution of dissolved to total LAPase and APase, but not with the percentage of dissolved to total AGase and BGase (Table 2). It is noteworthy that the strongest correlations between EEA (dissolved and total) and PHP and POC are those for LAPase and APase, which are the EEA exhibiting the highest rates (see 'Results'). In contrast, PON was only strongly

Table 2. Correlation coefficients $\left(\mathrm{r}_{\mathrm{S}}\right)$ between extracellular enzymatic activity (total, dissolved and percentage of dissolved relative to total) of AGase $(\alpha$-glucosidase), BGase ( $\beta$-glucosidase), LAPase (leucine aminopeptidase) and APase (alkaline phosphatase), and prokaryotic heterotrophic production (PHP) and suspended particulate organic matter (POC: particulate organic carbon; PON: particulate organic nitrogen). Sample size (n) varies between 50 and 93; ${ }^{*} \mathrm{p}<0.05,{ }^{* *} \mathrm{p}<0.01$

\begin{tabular}{|lllll|}
\hline & PHP & POC & PON & POC:PON \\
\hline Total AGase & $0.45^{* *}$ & $0.49^{* *}$ & 0.15 & $-0.29^{*}$ \\
Total BGase & $0.48^{* *}$ & $0.45^{* *}$ & 0.14 & $-0.29^{*}$ \\
Total LAPase & $0.52^{* *}$ & $0.51^{* *}$ & 0.20 & $-0.30^{* *}$ \\
Total APase & $0.67^{* *}$ & $0.64^{* *}$ & $0.36^{* *}$ & $-0.31^{* *}$ \\
Diss. AGase & $0.53^{* *}$ & $0.51^{* *}$ & 0.18 & $-0.37^{* *}$ \\
Diss. BGase & $0.46^{* *}$ & $0.42^{* *}$ & 0.16 & $-0.29^{*}$ \\
Diss. LAPase & $0.53^{* *}$ & $0.41^{* *}$ & 0.15 & $-0.37^{* *}$ \\
Diss. APase & $0.71^{* *}$ & $0.69^{* *}$ & $0.40^{* *}$ & $-0.40^{*}$ \\
$\%$ diss. AGase & -0.20 & 0.01 & -0.23 & -0.20 \\
$\%$ diss. BGase & $-0.32^{*}$ & -0.17 & -0.26 & -0.05 \\
$\%$ diss. LAPase & $-0.67^{* *}$ & $-0.48^{* *}$ & $-0.35^{*}$ & 0.19 \\
$\%$ diss. APase & $-0.62^{* *}$ & $-0.36^{* *}$ & -0.24 & 0.18 \\
\hline
\end{tabular}

significantly correlated with total APase $\left(\mathrm{r}_{\mathrm{S}}=0.36, \mathrm{p}<\right.$ $0.0001, \mathrm{n}=50)$ and dissolved APase $\left(\mathrm{r}_{\mathrm{S}}=0.40, \mathrm{p}<\right.$ $0.0001, \mathrm{n}=50$ ). In addition, the POC:PON ratio was also significantly correlated with the 4 dissolved and particulate EEA $\left(\mathrm{r}_{\mathrm{S}}, \mathrm{p}<0.0001\right)$, probably due to the lower influence of PON than of POC on prokaryotic metabolism (Table 2). The significant relation between total and dissolved EEA, and between EEA and the POM pool and prokaryotic metabolism suggests an active response to the organic matter pool by the prokaryotes.

The observed pattern of the relative contribution of dissolved to the total EEA is unlikely to be due to the measurement of these parameters under surface pressure rather than under in situ pressure conditions. Thus far, no consistent trend has emerged from studies on the effect of hydrostatic pressure on bathypelagic prokaryotic activity including EEA. There is evidence that deep-water prokaryotic activity may be overestimated if measured under decompressed conditions (Jannasch \& Wirsen 1982), while other studies report an inhibition of prokaryotic activity under decompressed conditions (Tamburini et al. 2003). It is well known that prokaryotic enzymes might be adapted to a specific hydrostatic pressure (Jannasch \& Taylor 1984, Somero 1992). In fact, Tamburini et al. (2002) showed that LAPase and APase rates measured in samples maintained under in situ pressure conditions were $\sim 2 \times$ higher than those measured under decompressed conditions. Thus, our reported EEA might have been increasingly underestimated with depth as compared to the in situ EEA; hence, the high EEA reported in the deep Atlantic might actually be even higher under in situ pressure conditions. Overall, however, there is no reason or evidence to assume that the pressure effect would act differently on the dissolved and the particulate EEA; thus, the relation between dissolved and total EEA reported here should be unaffected by potential pressure effects.

Recently accumulating evidence suggests that the particle-associated life mode of prokaryotes in the deep ocean might be more common than hitherto assumed. Arístegui et al. (2005) and Reinthaler et al. (2006) reported increasing nucleic acid content per cell with depth, which is indicative of a larger genome size, and in turn, might point to an opportunistic life style (Lauro \& Bartlett 2007). DeLong et al. (2006) found that deep-water prokaryotes are enriched in transposases, polysaccharide and antibiotic synthesis genes and high numbers of chaperone-encoding genes, 
all suggesting a predominantly particle-attached life mode. Recently, González et al. (2008) found that the genome of a representative of a common bacterioplankton group (Polaribacter sp. MED 152 of the Flavobacteria) contains a substantial number of genes for attachment to surfaces or particles, gliding motility, and polymer degradation. Kirchman (2008) commenting on the findings of González et al. (2008), indicated that

due to the fact that detrital particles are not very numerous in the oceans, the 'desert' between particles may be studded with colloids, gels, and various forms of highmolecular weight DOM, which are all potential sources of carbon and energy (p. 84-88)

Baltar et al. (2009b) found a relation between suspended POM and prokaryotic respiration in the dark ocean, suggesting that microbial life in the deep ocean is likely more dependent on slowly sinking or buoyant, laterally advected suspended particles than thus far anticipated.

The notion that microbes grow in association with (colloidal) particles in the deep ocean, where they may maintain relatively high metabolic activities, could also explain the high levels of dissolved EEA found in the dark realm of the ocean. However, the colloidal microenvironment where microbial assemblages might thrive is likely to be substantially altered during sample collection using standard methods, probably leading to the disruption of the size-continuum of the organic matter field. Consequently, new sampling strategies are needed to selectively collect deep ocean particles and, thus, decipher the actual role of particleattached versus free-living microbes in the deep ocean's biogeochemistry and ecology.

Acknowledgements. We thank the captain and crew of RV 'Pelagia' for their help during work at sea. M. Espino and I. J. Alonso-González performed the particulate organic matter analyses. We also thank 3 anonymous reviewers for their comments and suggestions to improve the manuscript. This research was supported by a predoctoral fellowship of the Spanish Ministry of Education and Science (AP2005-3932) to F.B., a grant of the Earth and Life Science Division of the Dutch Science Foundation (ALW-NWO; ARCHIMEDES project, 835.20.023) to G.J.H., and a grant of the Spanish Ministry of Education and Science to J.A. (Remolinos Oceánicos y Deposición Atmosférica (RODA) project; CTM 2004-06842C03/MAR). The work was carried out within the framework of the EU 'Networks of Excellence' MarBef and EurOceans.

\section{LITERATURE CITED}

Albertson NH, Nystrom T, Kjelleberg S (1990) Macromolecular synthesis during recovery of the marine Vibrio sp. S14 from starvation. J Gen Microbiol 136:2201-2207

Alderkamp AC, van Rijssel M, Bolhuis H (2007) Characterization of marine bacteria and the activity of their enzyme systems involved in degradation of the algal storage glucan laminarin. FEMS Microbiol Ecol 59:108-117
Allison SD (2005) Cheaters, diffusion and nutrients constrain decomposition by microbial enzymes in spatially structured environments. Ecol Lett 8:626-635

Aluwihare LI, Repeta DJ, Pantoja S, Johnson CG (2005) Two chemically distinct pools of organic nitrogen accumulate in the ocean. Science 308:1007-1010

Antia AN, Koeve W, Fischer G, Blanz $T$ and others (2001) Basin-wide particulate carbon flux in the Atlantic Ocean: regional export patterns and potential for atmospheric $\mathrm{CO}_{2}$ sequestration. Global Biogeochem Cycles 15: 845-862

Antranikian G (1992) Microbial degradation of starch. In: Wilkelman G (ed) Microbial degradation of natural products. John Wiley \& Sons, Weinheim, p 105-115

Arístegui J, Duarte CM, Gasol JM, Alonso-Sáez L (2005) Active mesopelagic prokaryotes support high respiration in the subtropical northeast Atlantic Ocean. Geophys Res Lett 32:L03608. doi:03610.01029/02004GL021863

Azam F (1998) Microbial control of oceanic carbon flux: the plot thickens. Science 280:694-696

Azam F, Cho BC (1987) Bacterial utilization of organic matter in the sea. In: Ecology of microbial communities. Cambridge University Press, Cambridge, p 261-281

Azam F, Long RA (2001) Sea snow microcosms. Nature 414: 495-498

Baltar F, Sintes E, Van Aken H, Gasol JM, Arístegui J, Herndl GJ (2009a) Prokaryotic extracellular enzymatic activity in relation to biomass production and respiration in the meso- and bathypelagic waters of the (sub)tropical Atlantic. Environ Microbiol 11:1998-2014

Baltar F, Arístegui J, Gasol JM, Sintes E, Herndl GJ (2009b) Evidence of prokaryotic metabolism on suspended particulate organic matter in the dark waters of the subtropical North Atlantic. Limnol Oceanogr 54:182-193

Benner R, Pakulski JD, McCarthy M, Hedges JI, Hatcher PG (1992) Bulk chemical characteristics of dissolved organic matter in the ocean. Science 255:1561-1564

Bevington PR, Robinson DK (2003) Data reduction and error analysis for the physical sciences. McGraw Hill, San Francisco, CA

> Bochdansky AB, Puskaric S, Herndl GJ (1995) Influence of zooplankton grazing on free dissolved enzymes in the sea. Mar Ecol Prog Ser 121:53-63

Chin WC, Orellana MV, Verdugo P (1998) Spontaneous assembly of marine dissolved organic matter into polymer gels. Nature 395:568-572

- Cho BC, Azam F (1988) Major role of bacteria in biogeochemical fluxes in the ocean's interior. Nature 332:441-443

Chrost RJ (1989) Characterization and significance of B-glucosidase activity in lake water. Limnol Oceanogr 34: 660-672

Chrost RJ (1990) Microbial ectoenzymes in aquatic environments. In: Overbeck J, Chrost RJ (eds) Aquatic microbial ecology: biochemical and molecular approaches. Springer, New York, p 47-78

Chrost RJ (1991) Environmental control of the synthesis and activity of aquatic microbial ectoenzymes. In: Chrost RJ (ed) Microbial enzymes in aquatic environments. Springer Verlag, New York, p 29-59

Chrost RJ, Rai H (1993) Ectoenzyme activity and bacterial secondary production in nutrient-improverished and nutrient-enriched freshwater mesocosms. Microb Ecol 25: $131-150$

> Davey KE, Kirby RR, Turley CM, Weightman AJ, Fry JC (2001) Depth variation of bacterial extracellular enzyme activity and population diversity in the northeastern North Atlantic Ocean. Deep-Sea Res II 48:1003-1017 
Decho AW (1990) Microbial exopolymer secretions in ocean environments: their role(s) in food webs and marine processes. Oceanogr Mar Biol Annu Rev 28:73-153

DeLong EF, Preston CM, Mincer T, Rich V and others (2006) Community genomics among stratified microbial assemblages in the ocean's interior. Science 311:496-503

Dick WA, Tabatabai MA (1992) Significance and potential uses of soil enzymes. In: Metting FB (ed) Soil microbial ecology. Marcel Dekker, New York, p 95-127

Ferron B, Mercier H, Speer K (1998) Mixing in the Romanche Fracture Zone. J Phys Oceanogr 28:1929-1945

Gianfreda L, Scarfi MR (1991) Enzyme stabilization: state of the art. Mol Cell Biochem 100:97-128

- González JM, Fernández-Gómez B, Fernández-Guerra A Gómez-Consarnau L and others (2008) Genome analysis of the proteorhodopsin-containing marine bacterium Polaribacter sp. MED152 (Flavobacteria). Proc Natl Acad Sci USA 105:8724-8729

Hashimoto S, Fujiwara K, Fuwa K, Saino T (1985) Distribution and characteristics of carboxypeptidase activity in pond, river, and seawater in the vicinity of Tokyo. Limnol Oceanogr 30:631-645

Healey FP (1980) Slope of the Monod equation as an indicator of advantage in nutrient competition. Microb Ecol 5: 281-286

Hoppe HG (1983) Significance of exoenzymatic activities in the ecology of brackish water: measurements by means of methylumbelliferyl-substrates. Mar Ecol Prog Ser 11: 299-308

Hoppe HG, Ullrich S (1999) Profiles of ectoenzymes in the Indian Ocean: phenomena of phosphatase activity in the mesopelagic zone. Aquat Microb Ecol 19:139-148

Hoppe HG, Ducklow H, Karrasch B (1993) Evidence for dependency of bacterial growth on enzymatic hydrolysis of particulate organic matter in the mesopelagic ocean. Mar Ecol Prog Ser 93:277-283

Hoppe HG, Arnosti C, Herndl GJ (2002) Ecological significance of bacterial enzymes in the marine environment. In: Burns RG, Dick RP (eds) Enzymes in the environment: activity, ecology, and applications. Marcel Dekker, New York, p 73-108

Jannasch HW, Taylor CD (1984) Deep-sea microbiology. Annu Rev Microbiol 38:487-514

Jannasch HW, Wirsen CO (1982) Microbial activities in undecompressed and decompressed deep-seawater samples. Appl Environ Microbiol 43:1116-1124

Karl DM, Knauer GA, Martin JH (1988) Downward flux of particulate organic matter in the ocean: a particle decomposition paradox. Nature 332:438-441

Karner M, Herndl GJ (1992) Extracellular enzymatic activity and secondary production in free-living and marine snow associated bacteria. Mar Biol 113:341-347

Karner M, Rassoulzadegan F (1995) Extracellular enzyme activity: indications for high short-term variability in a coastal marine ecosystem. Microb Ecol 30:143-156

Karrasch B, Ullrich S, Mehrens M, Zimmermann-Timm H (2003) Free and particle-associated extracellular enzyme activity and bacterial production in the lower Elbe Estuary, Germany. Acta Hydrochim Hydrobiol 31: 297-306

Keith SC, Arnosti C (2001) Extracellular enzyme activity in a river-bay-shelf transect: variations in polysaccharide hydrolysis rates with substrate and size class. Aquat Microb Ecol 24:243-253

Kim C, Nishimura Y, Nagata T (2007) High potential activity of alkaline phosphatase in the benthic nepheloid layer of a large mesotrophic lake: implications for phosphorus regeneration in oxygenated hypolimnion. Aquat Microb Ecol 49:303-311

Kirchman DL (2008) New light on an important microbe in the ocean. Proc Natl Acad Sci USA 105:8487-8488

Kirchman DL, Ducklow HW (1993) Estimating conversion factors for thymidine and leucine methods for measuring bacterial production. In: Kemp PF, Sherr BF, Sherr EB, Cole JJ (eds) Handbook of methods in aquatic microbial ecology. Lewis Publishers, Boca Raton, FL, p 513-517

Koike I, Nagata T (1997) High potential activity of extracellular alkaline phosphatase in deep waters of the central Pacific. Deep-Sea Res 44:2283-2294

> Koike I, Hara S, Terauchi K, Kogure K (1990) Role of submicrometre particles in the ocean. Nature 345:242-244

Lähdesmäki P, Piispanen R (1992) Soil enzymology: role of protective colloid systems in the preservation of exoenzyme activities in soil. Soil Biol Biochem 24:1173-1177

> Lauro FM, Bartlett DH (2007) Prokaryotic lifestyles in deep sea habitats. Extremophiles 12:15-25

> Lozzi I, Calami L, Fusi P, Bosetto M, Stotzky G (2001) Interaction of horseradish peroxidase with montmorillonite homoionic to $\mathrm{Na}^{+}$and $\mathrm{Ca}^{2+}$ : effects on enzymatic activity and microbial degradation. Soil Biol Biochem 33: 1021-1028

McLaren AD, Skujins J (1967) The environments of soil bacteria. In: Gray TRG, Parkinson D (eds) The ecology of soil bacteria. Liverpool University Press, Liverpool

Misic C, Castellano M, Fabiano M, Ruggierini N, Saggiomo V, Povero P (2006) Ectoenzymatic activity in surface waters: a transect from the Mediterranean Sea across the Indian Ocean to Australia. Deep-Sea Res I 53:1517-1532

- Moran SB, Charette MA, Pike SM, Wicklund CA (1999) Differences in seawater particulate organic carbon concentrations in samples collected using small- and large-volume methods: the importance of DOC adsorption to the filter blank. Mar Chem 67:33-42

Müller-Niklas G, Schuster S, Kaltenböck E, Herndl GJ (1994) Organic content and bacterial metabolism in amorphous aggregations of the northern Adriatic Sea. Limnol Oceanogr 39:58-68

> Nagata T, Kirchman DL (1990) Filtration-induced release of dissolved free amino acids: application to cultures of marine protozoa. Mar Ecol Prog Ser 68:1-5

Nagata T, Kirchman DL (1992) Release of macromolecular organic complexes by heterotrophic marine flagellates. Mar Ecol Prog Ser 83:233-240

Obayashi Y, Suzuki S (2008) Adsorption of extracellular proteases in seawater onto filters during size fractionation. J Oceanogr 64:367-372

Paul EA (1989) Soil microbiology and biochemistry. Academic Press, San Diego, CA

> Rath J, Schiller C, Herndl GJ (1993) Ectoenzymatic activity and bacterial dynamics along a trophic gradient in the Caribbean Sea. Mar Ecol Prog Ser 102:89-96

Rego JV, Billen G, Fontigny A, Someville M (1985) Free and attached proteolytic activity in water environments. Mar Ecol Prog Ser 21:245-249

Reinthaler $\mathrm{T}$, van Aken $\mathrm{H}$, Veth $\mathrm{C}$, Aristegui $\mathrm{J}$ and others (2006) Prokaryotic respiration and production in the mesoand bathypelagic realm of the eastern and western North Atlantic basin. Limnol Oceanogr 51:1262-1273

Sala MM, Karner M, Arin L, Marrasé C (2001) Measurement of ectoenzyme activities as an indication of inorganic nutrient imbalance in microbial communities. Aquat Microb Ecol 23:301-311

Smith DC, Simon M, Alldredge AL, Azam F (1992) Intense hydrolytic enzyme activity on marine aggregates and 
implications for rapid particle dissolution. Nature 359: 139-142

Somero GN (1992) Adaptation to high hydrostatic pressure. Annu Rev Physiol 54:557-577

Someville M, Billen G (1983) A method for determining exoproteolytic activity in natural waters. Limnol Oceanogr 28: 190-193

Tamburini C, Garcin J, Ragot M, Bianchi A (2002) Biopolymer hydrolysis and bacterial production under ambient hydrostatic pressure through a $2000 \mathrm{~m}$ water column in the NW Mediterranean. Deep-Sea Res II 49:2109-2123

Tamburini C, Garcin J, Bianchi A (2003) Role of deep-sea bacteria in organic matter mineralization and adaptation to hydrostatic pressure conditions in the NW Mediterranean Sea. Aquat Microb Ecol 32:209-218

Tamburini C, Garel M, Ali BA, Mérigot B, Kriwy P, Charrière B, Budillon G (2009) Distribution and activity of Bacteria and Archaea in the different water masses of the Tyrrhenian Sea. Deep-Sea Res II 56:700-712

UNESCO (1994) Protocols for the Joint Global Ocean Flux Study (JGOFS) core measurement. Intergovernmental Oceanographic Commission. Manual and Guides 29:169

Verdugo P, Alldredge AA, Azam F, Kirchman DL, Passow U, Santschi P (2004) The oceanic gel phase: a bridge in the DOM-POM continuum. Mar Chem 92:67-85

Verdugo $\mathrm{P}$, Orellana MV, Chin WC, Petersen TW, van den Eng G, Benner R, Hedges JI (2008) Marine biopolymer self-assembly: implications for carbon cycling in the ocean. Faraday Discuss 139:393-398

Vetter YA, Deming JW (1999) Growth rates of marine bacterial isolates on particulate organic substrates solubilized by

Editorial responsibility: Fereidoun Rassoulzadegan, Villefranche-sur-Mer, France freely released extracellular enzymes. Microb Ecol 37: 86-94

Vetter YA, Deming JW, Jumars PA, Krieger-Brockett BB (1998) A predictive model of bacterial foraging by means of freely released extracellular enzymes. Microb Ecol 36: 75-92

- Weiss MS, Abele U, Weckesser J, Welte W, Schiltz E, Schulz GE (1991) Molecular architecture and electrostatic properties of bacterial porin. Science 254:1627-1630

Wells ML (1998) A neglected dimension. Nature 391:530-531

- Wells ML, Goldberg ED (1992) Marine submicron particles. Mar Chem 40:5-18

Wetzel RG (1991) Extracellular enzymatic interactions: storage, redistribution, and interspecific communication. In: Chrost RJ (ed) Microbial enzymes in aquatic environments. Springer Verlag, New York, p 6-28

Williams C, Jochem FJ (2006) Ectoenzyme kinetics in Florida Bay: implications for bacterial carbon source and nutrient status. Hydrobiologia 569:113-127

Zaccone R, Monticelli LS, Seritti A, Santinelli C and others (2003) Bacterial processes in the intermediate and deep layers of the Ionian Sea in winter 1999: vertical profiles and their relationship to the different water masses. J Geophys Res 108:8117

Ziervogel K, Arnosti C (2008) Polysaccharide hydrolysis in aggregates and free enzyme activity in aggregate-free seawater from the north-eastern Gulf of Mexico. Environ Microbiol 10:289-299

Ziervogel K, Karlsson E, Arnosti C (2007) Surface associations of enzymes and of organic matter: consequences for hydrolytic activity and organic matter remineralization in marine systems. Mar Chem 104:241-252

Submitted: April 23, 2009; Accepted: August 24, 2009 Proofs received from author(s): January 28, 2010 